\title{
ANALISIS KESALAHAN MAHASISWA DALAM MENYELESAIKAN SOAL SISTEM PERSAMAAN LINEAR MENGGUNAKAN OPERASI BARIS ELEMENTER
}

\author{
Nur Qomariyah Nawafilah \\ nq.nawafil@yahoo.com \\ Teknik Informatika, Fakultas Teknik, Universitas Islam Lamongan
}

\begin{abstract}
Abstrak
Dalam proses pembelajaran perlu dilihat, dievaluasi, diperbaiki, bahkan ditingkatkan kualitas proses dan hasil pembelajaran matematika yang telah dilakukan. Hal ini bertujuan supaya kesulitan belajar yang terjadi dan dialami siswa pada materi bahasan tertentu dapat dianalisis dan diberikan solusinya. Dengan begitu, harapannya akan terjadi perubahan perilaku dan prestasi belajar matematika yang lebih baik dan tidak melakukan kesalahan lagi. Berdasakan hasil obesrvasi peneliti pada mata kuliah aljabar linear dan matriks diperoleh bahwa masih banyak mahasiswa yang melakukan kesalahan dalam menyelesaikan soal-soal sistem persamaan linear menggunakan operasi baris elementer. Tujuan penelitian ini adalah untuk menganalisis jenis kesalahan mahasiswa dalam menyelesaikan soal-soal sistem persamaan linear menggunakan operasi baris elementer beserta faktor-faktor yang mempengaruhi kesalahan tersebut. Penelitian ini menggunakan metode deskriptif dengan pendekatan kualitatif. Hasil penelitian menunjukkan bahwa untuk jenis kesalahan mahasiswa yang berkaitan dengan konsep sebesar 28,13\%, kesalahan yang berkaitan dengan kesalahan hitung sebesar 40,63\%, kesalahan penulisan dan penggunaan tanda sebesar $21,88 \%$, kesalahan dengan menjawab sembarang sebesar 25\%. Faktor internal yang mempengaruhi mahasiswa melakukan kesalahan yakni: 1) kecerobohan mahasiswa; 2) minat yang kurang terhadap mata kuliah matematika; 3) kurangnya penguasaan konsep; 4) kepercayaan diri yang rendah. Sedangkan faktor eksternal yang mempengaruhi yakni lingkungan belajar yang bising dan pengaruh pergaulan yang salah.
\end{abstract}

\section{Kata kunci: Analisis kesalahan, Sistem persamaan linear, Operasi baris elementer}

\section{PENDAHULUAN}

Matematika merupakan mata pelajaran yang diajarkan hampir di semua jenjang pendidikan mulai dari sekolah dasar, sekolah menengah, hingga perguruan tinggi. Hal ini disebabkan matematika merupakan ilmu yang sangat penting. Selain mempelajari tentang hitung menghitung, matematika juga dapat digunakan untuk membuktikan kebenaran ide dan memecahkan masalah melalui cara berpikir yang logis dan terstruktur. Keterampilan mengerjakan soal matematika yang sesuai sangat diperlukan dalam mempelajari bidang studi lain.

Agar pembelajaran matematika dapat berjalan dengan sukses, maka peran guru sangatlah penting. Pembelajaran yang dilakukan di kelas tidak lagi harus berpusat pada guru, namun lebih diarahkan ke siswa. Siswa harus dapat mengkonstruksi pemahamannya sendiri dan peran guru hanya sebagai fasilitator. Dimana menurut paham konstruktivisme terjadi perubahan yakni dari paradigma mengajar ke paradigma belajar.

Menurut (Manibuy, 2014: 933), dalam proses pembelajaran perlu dilihat, dievaluasi, diperbaiki, bahkan ditingkatkan kualitas proses dan hasil pembelajaran matematika yang telah dilakukan. Hal ini bertujuan supaya kesulitan belajar matematika yang terjadi dan dialami siswa pada materi dan topik bahasan tertentu dapat dianalisis dan diberikan solusi pemecahannya. Dengan begitu, harapannya akan terjadi perubahan perilaku dan prestasi belajar matematika yang lebih baik dan tidak melakukan kesalahan lagi.

Menurut Ischak dan Warji (1987: 19), terdapat dua faktor yang menyebabkan kesalahan siswa dalam matematika, yaitu faktor internal dan faktor eksternal. Faktor internal yaitu faktor-faktor yang berasal dari dalam diri siswa itu sendiri baik yang bersifat biologis maupun yang bersifat psikologis 
misalnya kecerdasan, kelemahan fisik, sikap dan kebiasaan yang salah dalam mempelajari bahan pelajaran tertentu. Faktor eksternal yaitu faktor-faktor yang berasal dari luar diri siswa itu sendiri, berupa lingkungan, baik yang berupa lingkungan alam misalnya tempat belajar, suasana, cuaca, penerangan, dan sebagainya, maupun yang berupa lingkungan sosial yaitu yang berhubungan dengan pergaulan manusia.

Jenis-jenis kesalahan yang akan dicari dalam penelitian ini adalah berbagai macam jenis kesalahan yang dilakukan siswa dalam menyelesaikan soal matematika materi sistem persamaan linear dengan menggunakan operasi baris elementer. Berdasarkan hasil adaptasi dari Rosmaiyadi (2018: 63) jenis kesalahan dikelompokkan dalam empat jenis yakni sebagai berikut ini: 1) Kesalahan konsep, yaitu kesalahan siswa berkaitan dengan konsep dasar yang dimilikinya; 2) Kesalahan dalam menghitung; 3) Kesalahan tanda, yang seharusnya negatif menjadi positif atau sebaliknya; 4) Jawaban yang sembarang.

Sistem Persamaan Linear merupakan salah satu materi matematika yang diajarkan pada mahasiswa semester 2 prodi Teknik Informatika Universitas Islam Lamongan. Materi ini masuk dalam mata kuliah Aljabar Linear dan Matriks dengan bobot 3 SKS. Dalam meyelesaikan soal Sistem Persamaan Linear terdapat suatu operasi yang dinamakan Operasi Baris Elementer (OBE) yang mana dalam menyelesaikan soal yang berkaitan dengan operasi ini diperlukan ketelitian tingkat tinggi. Menurut hasil obesrvasi peneliti yang juga sebagai pengampu mata kuliah ini diperoleh bahwa mahasiswa masih banyak yang melakukan kesalahan dalam menggunakan operasi ini. Dari hasil Quis II yang memang menguji tentang operasi ini menunjukkan bahwa sebanyak $55 \%$ mahasiswa mendapat nilai $<70$ atau jika dikonversikan ke nilai huruf berarti mendapat nilai $\mathrm{C}$ ke bawah.
Berdasarkan uraian di atas, maka peneliti tertarik untuk menganalisis dan mendeskripsikan jenis kesalahan mahasiswa dalam menyelesaikan soal-soal sistem persamaan linear menggunakan operasi baris elementer beserta faktorfaktor yang mempengaruhi kesalahan tersebut.

\section{METODE}

Penelitian ini menggunakan metode deskriptif, yang mana menurut Nawawi (2012: 67) metode deskriptif adalah prosedur pemecahan masalah yang diselidiki dengan menggambarkan/ melukiskan keadaan subyek/ objek penelitian (seseorang, lembaga, masyarakat, dan lain-lain) pada saat sekarang berdasarkan fakta-fakta yang tampak, atau sebagaimana adanya. Sedangkan pendekatan yang dilakukan dalam penelitian ini adalah pendekatan kualitatif, karena data yang dikumpulkan bersifat kualitatif dan tidak mengunakan alat-alat pengukur.

Subjek dalam penelitian ini adalah mahasiswa kelas IIC Teknik Informatika Unisla yang berjumlah 32 orang. Sedangkan objek dalam penelitian ini adalah jenis-jenis kesalahan dan faktor-faktor yang mempengaruhi terjadinya kesalahan dalam menyelesaikan soal sistem persamaan linear menggunakan Operasi baris elementer.

Teknik pengumpulan data dalam penelitian ini menggunakan teknik tes tertulis dan wawancara. Tes tertulis yang digunakan berupa soal matematika tentang penyelesaian sistem persamaan linear menggunakan operasi baris elementer. Wawancara (interview) merupakan teknik pengumpulan data untuk memperoleh informasi yang digali dari sumber data langsung melalui tanya jawab. Wawancara dilaksanakan guna memperoleh informasi berkaitan dengan alasan mahasiswa dalam menjawab soal sistem persamaan linear yang diberikan serta faktor yang 
mempengaruhi mahasiswa melakukan kesalahan tersebut. Instrumen yang digunakan dalam penelitian ini adalah Soal Tes dan Pedoman Wawancara.

Tes yang dimaksud dalam penelitian ini adalah tes tertulis yang berbentuk uraian (essay) untuk mengetahui sejauh mana mahasiswa memahami suatu soal atau masalah yang diteskan dan memperkecil kerjasama antar mahasiswa dalam mengerjakan soal (Arikunto, 2008: 163). Sedangkan wawancara yang dilakukan merupakan wawancara tak terstruktur (bebas). "Wawancara tidak terstruktur adalah wawancara bebas dimana peneliti tidak menggunakan pedoman wawancara yang telah tersusun secara sistematis dan lengkap untuk pengumpulan datanya" Sugiyono (2012: 74). Menurut (Arikunto 2007: 30) "Wawancara bebas yakni wawancara dimana responden mempunyai kebebasan untuk mengutarakan pendapatnya, tanpa dibatasi oleh patokan-patokan yang telah dibuat oleh subjek evaluasi".

Secara garis besar, teknik analisis data yang digunakan dalam penelitian ini mengacu pada pendapat Miles dan Huberman (Sugiyono, 2012) dengan langkah-langkah sebagai berikut: (1) reduksi data, yaitu kegiatan yang mengacu pada proses pemilihan dan pengidentifikasian data yang memiliki makna jika dikaitkan dengan masalah penelitian sehingga data yang dihasilkan akan memberikan gambaran yang jelas; (2) penyajian data dalam bentuk tabel rekapitulasi dan dilengkapi dengan teks yang bersifat naratif mengenai kesalahan mahasiswa dalam menyelesaikan soal sistem persamaan linear; (3) penarikan kesimpulan, yaitu sebagai kesimpulan awal tentang jenis-jenis kesalahan beserta faktor penyebab terjadinya kesalahan yang dilakukan mahasiswa.

Proses kegiatan analisis data kualitatif dilakukan dengan langkahlangkah sebagai berikut: (1) mengoreksi jawaban tes tulis mahasiswa, (2) menggolongkan jenis kesalahan mahasiswa untuk tiap butir soal, (3) menghitung persentase jumlah mahasiswa untuk tiap jenis kesalahan, (4) menghitung persentase jumlah mahasiswa yang melakukan kesalahan untuk tiap butir soal, (5) menentukan empat mahasiswa yang akan diwawancarai, (6) mewawancarai empat mahasiswa terpilih sebagai subjek penelitian untuk menggali informasi lebih dalam tentang alasan mereka menuliskan jawaban yang telah dikumpulkan beserta faktor penyebab sehingga mereka melakukan kesalahan dalam menyelesaikan soal sistem persamaan linear menggunakan OBE.

\section{PEMBAHASAN}

Setelah dilakukan analisis data sesuai dengan prosedur yang telah dipaparkan sebelumnya, maka penulis merangkum hasilnya dalam tabel berikut:

Tabel 1. Rekapitulasi Kesalahan Mahasiswa dalam Menyelesaikan Soal Tes

\begin{tabular}{|c|c|c|c|c|c|}
\hline \multirow{2}{*}{ No Soal } & \multicolumn{4}{|c|}{ Banyaknya Jenis Kesalahan (\%) } & \multirow[t]{2}{*}{ Total Kesalahan } \\
\hline & KK & KM & $\mathrm{KT}$ & $\mathrm{JS}$ & \\
\hline 1 & 9,38 & 6,25 & 0 & 3,13 & 18,75 \\
\hline 2 & 3,13 & 9,38 & 12,5 & 6,25 & 31,25 \\
\hline 3 & 6,25 & 9,38 & 3,13 & 6,25 & 25 \\
\hline 4 & 9,38 & 15,63 & 6,25 & 9,38 & 40,63 \\
\hline Total Kesalahan & $28,13 \%$ & $40,63 \%$ & $21,88 \%$ & $25 \%$ & \\
\hline
\end{tabular}

Keterangan Jenis Kesalahan:

$\mathrm{KK}=$ Kesalahan Konsep

$\mathrm{KM}=$ Kesalahan dalam Menghitung

KT = Kesalahan Tanda

JS = Jawaban Sembarang. 
Berdasarkan Tabel 1 di atas, banyaknya kesalahan yang dilakukan mahasiswa dalam mengerjakan soal tes tentang persamaan linear menggunakan operasi baris elementer dijelaskan sebagai berikut:

1. Untuk jenis kesalahan pertama yaitu kesalahan konsep, dari empat butir soal yang diberikan kepada 32 orang mahasiswa, terdapat $28,13 \%$ mahasiswa melakukan kesalahan konsep.

2. Untuk jenis kesalahan kedua yaitu kesalahan dalam menghitung, dari empat butir soal yang diberikan kepada 32 orang mahasiswa, terdapat $40,63 \%$ mahasiswa melakukan kesalahan dalam menghitung.

3. Untuk jenis kesalahan ketiga yaitu kesalahan tanda, dari empat butir soal yang diberikan kepada 32 orang mahasiswa, terdapat $21,88 \%$ mahasiswa melakukan kesalahan tanda.

4. Untuk jenis kesalahan kelima yaitu jawaban yang sembarang, dari empat butir soal yang telah diberikan kepada 32 orang mahasiswa, terdapat sebanyak $25 \%$ mahasiswa memberikan jawaban yang sembarang.

Selanjutnya, untuk mendapatkan informasi lebih jauh mengenai faktor penyebab kesalahan-kesalahan mahasiswa dalam menyelesaikan soal tes tentang persamaan linear menggunakan operasi baris elementer, maka dilakukan wawancara terhadap beberapa orang mahasiswa terpilih. Kriteria pemilihan mahasiswa yang akan diwawancarai yakni yang mendapatkan nilai tes essay di bawah rata-rata nilai kelas dan mahasiswa tersebut dapat berkomunikasi dengan baik. Harapannya supaya informasi yang digali dapat terjawab dengan jelas dan maksimal. Setelah dilakukan evaluasi akhirnya terpilih empat mahasiswa sebagai subjek penelitian, adapun mahasiswa yang diambil antara lain yakni: DA, EV, NS, dan AT

Hasil wawancara dengan keempat mahasiswa tersebut terangkum seperti berikut:

1. DA merupakan mahasiswa teknik informatika angkatan 2018 yang saat ini sedang semester II. DA mengaku bahwa dia kurang teliti dalam proses hitung-menghitung. Ketika dilakukan wawancara, terbukti bahwa DA dapat menjawab dengan benar langkah penyelesaian soal yang diberikan, namun pada proses perhitungan dia ceroboh dan tidak teliti dengan tanda positif atau negatifnya sehingga hasilnya salah. Selain itu, DA juga mengaku bahwa dia merasa terganggu dengan suara bising gedung sebelah yang sedang dilakukan pembangunan. Hal itu menurut dia mengganggu konsentrasi belajar.

2. EV merupakan mahasiswa teknik informatika angkatan 2018 yang saat ini sedang semester II. Dia mengaku bahwa dari awal memang kurang minat dengan matematika. Sejak duduk di bangku sekolah dasar dan sekolah menengah dia selalu mendapat nilai matematika yang rendah sehingga dia tidak suka dengan pelajaran satu ini. EV tidak menyangka jika dalam prodi TI dia harus bertemu lagi dengan mata kuliah yang berhubungan dengan matematika. Karena ketidakberminatannya ini, EV sering absen pada mata kuliah aljabar linear dan matriks. Hanya saat Quis, UTS, dan UAS saja yang dapat dipastikan EV masuk.

3. NS merupakan mahasiswa teknik informatika angkatan 2018 yang saat ini sedang semester II. NS tergolong mahasiswa yang rajin, dia selalu masuk dan mengikuti perkuliahan serta memperhatikan penjelasan yang diberikan dosen. NS mengaku faham dengan contoh-contoh yang diberikan. Namun saat diberikan soal yang baru, 
NS kesulitan dalam mengerjakannya. Dia mengaku bingung jika soalnya dirubah sedikit saja. Hal ini menunjukkan jika NS kurang menguasai konsep. Sedangkan untuk bertanya pada dosen NS mengaku malu atau tidak percaya diri. Dia takut jika pertanyaannya membuat teman sekelasnya tertawa karena dianggap gampang. Selain itu, NS juga merasa terganggu dengan kebisingan pembangungan gedung yang berada tepat di sebelah gedung teknik. Hal itu membuatnya semakin kurang bisa konsentrasi.

4. AT merupakan mahasiswa teknik informatika angkatan 2018 yang saat ini sedang semester II. Di awal-awal perkuliahan Aljabar Linear dan Matriks, AT selalu hadir dan mengikuti proses belajar dengan baik. Dia juga rajin mencatat penjelasan yang diberikan. Namun setelah dipengaruhi teman-temannya untuk membolos, AT mulai jarang masuk kuliah. Dia diajak temannya nongkrong di warung kopi. Kadang meski masuk kuliahpun, AT sering telat. Hal ini menyebabkan AT ketinggalan materi dan tidak dapat mengerjakan soal-soal yang diberikan. Banyaknya warung kopi disekitar kampus kadang menjadi godaan tersendiri bagi mahasiswa. Apalagi prodi TI yang mahasiswanya mayoritas laki-laki.

\section{KESIMPULAN}

Berdasarkan hasil penelitian dan pembahasan dapat disimpulkan bahwa:

1. Jenis-jenis kesalahan mahasiswa dalam menyelesaikan soal sistem persamaan linear menggunakan operasi baris elementer antara lain adalah sebagai berikut:

a. Kesalahan yang berkaitan dengan pemahaman konsep, persentase kesalahan yang dilakukan oleh 32 mahasiswa pada kesalahan jenis ini sebanyak $28,13 \%$. b. Kesalahan yang berkaitan dengan proses menghitung, persentase kesalahan yang dilakukan oleh 32 mahasiswa pada kesalahan jenis ini sebanyak $40,63 \%$.

c. Kesalahan tanda, yang seharusnya positif menjadi negatif atau sebaliknya, persentase kesalahan yang dilakukan oleh 32 mahasiswa pada kesalahan jenis ini sebanyak $21,88 \%$.

d. Kesalahan karena memberikan jawaban sembarang, persentase kesalahan yang dilakukan oleh 32 mahasiswa pada kesalahan jenis ini sebanyak $25 \%$.

2. Faktor-faktor yang menyebabkan kesalahan mahasiswa dalam menyelesaikan soal sistem persamaan linear menggunakan operasi baris elementer adalah sebagai berikut:

a. Faktor internal atau dari dalam diri mahasiswa yaitu: 1) kecerobohan mahasiswa dalam proses perhitungan dan kurang teliti; 2) minat mahasiswa yang kurang terhadap mata kuliah matematika; 3) kurangnya mahasiswa dalam menguasai konsep; 4) kurangnya percaya diri mahasiswa untuk bertanya di kelas.

b. Faktor eksternal atau dari luar yaitu: 1) lingkungan belajar yang bising membuat konsentrasi mahasiswa terganggu; dan 2) pengaruh pergaulan yang salah membuat mahasiswa sering absen sehingga ketinggalan materi.

\section{DAFTAR PUSTAKA}

Arikunto, Suharsimi. 2007. Dasar-dasar Evaluasi Pendidikan (Edisi Revisi). Jakarta: PT Bumi Aksara.

Arikunto, Suharsimi. 2008. Dasar-dasar Evaluasi Pendidikan (Edisi Revisi). Jogyakarta : Bumi Aksara 
Ischak dan Warji. 1987. Program Remedial dalam Proses Belajar Mengajar. Yogyakarta: Liberty

Manibuy, Ronald. 2014. Analisis Kesalahan Siswa dalam Menyelesaikan Soal Persamaan Kuadrat Berdasarkan Taksonomi Solopada Kelas X SMA Negeri 1 Plus di Kabupaten Nabire - Papua. Jurnal Elektronik Pembelajaran Matematika.Vol.2, No.9, November.

Nawawi, Hadari. 2012. Metode Penelitian Bidang Sosial. Yogyakarta: Gadjah Mada University Press
Rosmaiyadi. 2018. Analisis Kesalahan Penyelesaian Soal Aljabar Pada Mahasiswa Program Studi Pendidikan Matematika STKIP Singkawang. Journal Pendidikan Matematika Volume 12, No. 1, Januari 2018, pp. 59-70

Sugiyono. 2012. Memahami Penelitian Kualitatif. Bandung: Alfabeta

Tall, D., \& Razali, M. 1993. Diagnosing Students' Difficulties in Learning Mathematics.

International Journal of Mathematics Education in Science \& Technology, Vol.24, 209- 202. 